\title{
Current Issues of Evaluating the Effectiveness of Public Procurement
}

\section{Problemas Actuales De La Evaluación De La Eficacia De La Contratación Pública}

\author{
Natalia Alekseevna PRODANOVA \\ Plekhanov Russian University of Economics, Moscow, Russian Federation \\ ORCID: 0000-0001-5140-2702 \\ Elena Ivanovna ZATSARINNAYA \\ Plekhanov Russian University of Economics, Moscow, Russian Federation \\ ORCID: 0000-0002-9400-4285
}

Tatiana Aleksandrovna POLYANSKAYA

Main control Department of Moscow, Moscow, Russian Federation ORCID: 0000-0001-6730-6950

\section{Olga Sergeevna BURYAKOVA}

Institute of Service and Entrepreneurship (branch) of the Federal State Budgetary Educational Institution of Higher Education "Don State Technical University" in Shakhty, Rostov Region.

Russian Federation

ORCID: 0000-0002-8798-5783

\section{Natalya Valeryevna CHUMAKOVA}

Azov-Black Sea Engineering Institute of Don State Agrarian University, Zernograd, Russian

Federation

ORCID: 0000-0003-0132-9832

Received 09-08-20 Revised 10-10-20

* Correspondence

Email: prodanova-00@mail.ru
Accepted 12-12-20 On line 03-12-21

\section{Citation:}

\footnotetext{
Natalia Alekseevna PRODANOVA, Elena Ivanovna Zatsarinnaya, Tatiana Aleksandrovna Polyanskaya , Olga Sergeevna BURYAKOVA, Natalya Valeryevna CHUMAKOVA. (). Current Issues of Evaluating the Effectiveness of Public Procurement. Propósitos y Representaciones, 9 (SPE3), e1137. Doi: http://dx.doi.org/10.20511/pyr2021.v9nSPE3.1137
} 


\begin{abstract}
Public procurement under the contract system plays an important role in the development of the country's economy. The volume of state ownership and the volume of public procurement are impressive in their scale. Within the framework of the contract system, one of the priority goals is to increase the efficiency of state and municipal procurement. This article analyzes the existing indicators of the effectiveness of state and municipal procurement and provides recommendations for expanding the range of these indicators.
\end{abstract}

Keywords: evaluation, efficiency, public procurement, procurement procedures, methodology

\title{
Resumen
}

La contratación pública bajo el sistema de contratos juega un papel importante en el desarrollo de la economía del país. El volumen de propiedad estatal y el volumen de contratación pública son impresionantes en su escala. En el marco del sistema de contratos, uno de los objetivos prioritarios es aumentar la eficiencia de las adquisiciones estatales y municipales. Este artículo analiza los indicadores existentes de efectividad de las adquisiciones estatales y municipales y brinda recomendaciones para ampliar la gama de estos indicadores.

Palabras clave: evaluación, eficiencia, contratación pública, procedimientos de contratación, metodología

\section{Introduction}

To date, the evaluation of the effectiveness of procurement activities plays an important role both for end users and other procurement participants, and for the economy as a whole. Public and municipal procurement has been an integral part of meeting the needs of society for many years.

The problem of procurement efficiency is regulated by Article 1 of the Federal Law 44FZ, which defines the achievement of procurement efficiency as one of the goals, and also regulates the principle of efficiency as one of the principles of implementation of this law. The implementation of the efficiency principle implies the implementation of procurement processes for the needs of state and municipal organizations in accordance with the set goals and objectives.

The essence of the principle of effective use of budget funds is established by Article 34 "Budget Code of the Russian Federation" of 31.07.1998 No. 145-FZ (ed. from 22.04.2020) (hereinafter-145-FZ): "The principle of effective use of budget funds means that when drawing up and executing budgets, participants in the budget process within the budget powers established by them must proceed from the need to achieve the specified results using the least amount of funds (economy) and (or) achieve the best result using the amount of funds (efficiency) determined by the budget" (Budget Code of the Russian Federation No. 145-FZ of 31.07.1998).

Article 13 of the 44-FZ in order to achieve procurement efficiency indicates that the validity of purchases is mandatory. Justification is subject to each object of purchase, maximum starting price of contract, method of selecting a supplier and requirements for participants in the purchase. Assessment of the validity of the implemented purchases is carried out in the course of audit control checks.

The bodies responsible for conducting the audit are the Accounts Chamber of the Russian Federation, control and accounting bodies of municipal and regional levels. For socially significant areas of activity, public procurement control is also established, which can be carried out by public associations of citizens. 


\section{Methods}

The following methods were used in the study: analysis of the problem and subject of the study, a holistic approach to the study of public procurement management, study of sources, and methods of empirical research: analysis and synthesis, methods of systematization and classification of theoretical and practical data.

\section{Results}

The traditional assessment of the effectiveness of public procurement, which currently exists, is an assessment of the effectiveness of spending budget funds for each specific purchase. This assessment allows you to determine the budget savings for a specific purchase, without conducting an analysis and evaluation of the order placement system.

Table 1. The degree of efficiency of the customer's work, depending on the value of the savings indicator (Lapin \& Kiseleva, 2020)

\begin{tabular}{|c|c|c|c|}
\hline $\begin{array}{l}\text { Value of the } \\
\text { savings } \\
\text { indicator }\end{array}$ & $\begin{array}{l}\text { Degree of } \\
\text { effectiveness }\end{array}$ & $\begin{array}{c}\text { Conditionality of the degree } \\
\text { of effectiveness }\end{array}$ & The customer actions \\
\hline 1 & 2 & 3 & 4 \\
\hline $\mathrm{E}=0$ & Inefficient & $\begin{array}{l}\text { Single bidder, no bidders, } \\
\text { procurement outside of } \\
\text { competitive procedures }\end{array}$ & $\begin{array}{l}\text { Additional market research, } \\
\text { attracting suppliers }\end{array}$ \\
\hline$E<5 \%$ & Low & $\begin{array}{l}\text { Probability of very accurate } \\
\text { determination of the } \\
\text { maximum starting price of } \\
\text { contract by the customer }\end{array}$ & $\begin{array}{l}\text { The need for additional market } \\
\text { research, attracting suppliers }\end{array}$ \\
\hline $5 \%<\mathrm{E}<10 \%$ & Normal & $\begin{array}{l}\text { The customer's actions are } \\
\text { accurate }\end{array}$ & $\begin{array}{l}\text { There is no need for additional } \\
\text { adjustments in the actions of } \\
\text { the customer }\end{array}$ \\
\hline $10 \%<\mathrm{E}<20 \%$ & High & $\begin{array}{l}\text { The customer's actions are } \\
\text { accurate }\end{array}$ & $\begin{array}{l}\text { It is necessary to pay attention } \\
\text { to the performance of the } \\
\text { contract by the supplier }\end{array}$ \\
\hline$E>20 \%$ & Very high & $\begin{array}{l}\text { It may be the result of unfair } \\
\text { actions of the winner, } \\
\text { incorrect calculation of the } \\
\text { maximum starting price of } \\
\text { contract }\end{array}$ & $\begin{array}{c}\text { Pay special attention to } \\
\text { procurement with unjustified } \\
\text { efficiency }\end{array}$ \\
\hline \multicolumn{4}{|c|}{ 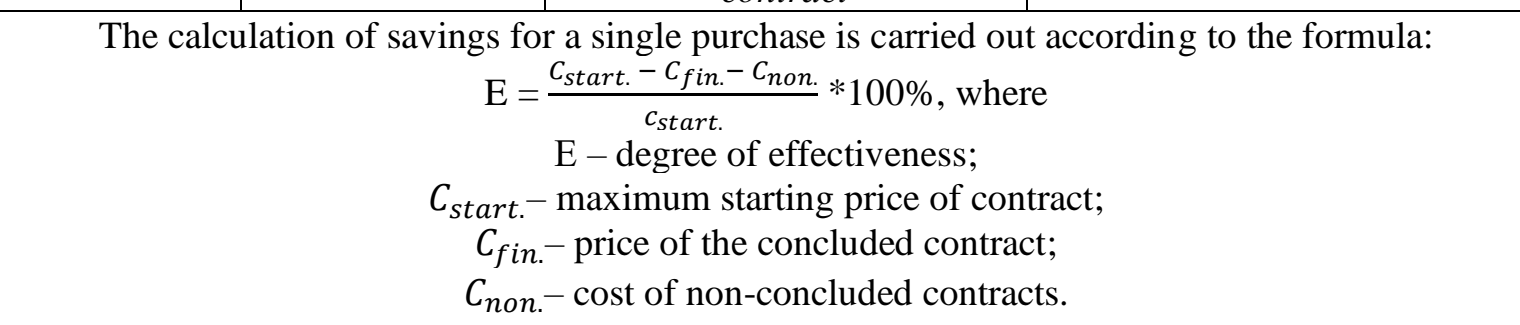 } \\
\hline
\end{tabular}

The Main Procurement Portal (Unified Information System in the field of procurement) offers a methodology for calculating cost savings based on the results of concluding contracts. The essence of the methodology is the calculation of cost savings based on the results of concluding public procurement contracts (absolute and relative values) (http://zakupki.gov.ru/epz/main/public/home.html). The indicator (absolute value) is the difference between the maximum starting price of contract in the implementation of state and municipal procurement and its actual value, which was specified in the contract concluded with the supplier (contractor, contractor). This indicator $\mathrm{AP}_{\text {economy }}$ (formula 1) is calculated only for existing contracts and together with the lot associated with them. The calculation formula is as follows: 


$$
\mathrm{AP}_{\text {economy }}=N *\left(\frac{P_{i}}{\sum P_{i}}\right)-P_{i} \text {, where }
$$

$\mathrm{AP}_{\text {economy }}$ - absolute value of cost savings;

$\mathrm{N}$ - maximum starting price of contract, which is specified for this customer and lot;

$P_{i}$ - price of one contract;

$\sum P_{i}-$ this is the sum of the prices of all contracts for a given customer and lot.

If the indicator $\mathrm{AP}_{\text {economy }}<0, \mathrm{AP}_{\text {economy }}$ remains empty. If several contracts are concluded for one lot with several participants, $\mathrm{AP}_{\text {economy }}$ (the absolute value of savings) will be calculated for each contract in the lot and for each contract in the contract register (http://zakupki.gov.ru/epz/main/public/home.html).

When calculating the indicator of the absolute value of savings, the following items are not taken into account:

- lots, as well as contracts related to these lots with unidentified maximum starting price of contract;

- contracts in the contract register, as well as related lots with unspecified contract prices;

- purchases that are canceled;

- contracts that have been cancelled.

Next, we will consider how the cost savings are calculated based on the results of concluding public procurement contracts (relative value), the indicator " OP " economy for lots and related contracts (formula 2).

$$
O P_{\text {economy }}=\frac{\text { Cost savings based on the results of concluding contracts (absolute value) }}{\text { maximum starting price of contract }} * 100 \%
$$

Moreover, in the calculation maximum starting price of contract is taken, those items for which savings (absolute value) $\geq 0$. The value of the index $\mathrm{OP}_{\text {economy }}$ is a percentage figure is also calculated at the date of conclusion of the contract. When calculating the number of contracts concluded:

- the number of contracts published in the contract register is taken into account;

- cancelled contracts are not included in the indicator;

- the status of the contract in this case is "Published";

- the date of conclusion of the contract is the date of formation of the indicator.

When determining the price of concluded contracts:

- the price of contracts is taken, which is published in the contract register;

- cancelled contracts are not included in the indicator;

- the status of the contract in this case is "Published";

- the date of conclusion of the contract is the date of formation of the indicator.

When calculating the number of published notifications:

- notifications with the status "Published" for the first version of the notification and with the date of placement of this version falling within the reporting period are accepted for accounting;

- notifications for orders that are subsequently canceled by the customer are included in the indicator;

- the facts of posting changes to notifications are not included in the indicator (www.zakupki.gov.ru/epz/main/public/documents/Calculation_methods.docx).

When evaluating the effectiveness of government orders, it is advisable to use both estimates at the same time; the first is to conduct an assessment for each purchase and comprehensively conduct the final reporting period. As well, it should be done in sectors of procurement, by individual customers, and in all the entire system of public procurement in general (http://zakupki.gov.ru/epz/main/public/home.html).

However, key performance indicators are not limited to those established by national / regional regulations.

Therefore, the Accounts Chamber of the Russian Federation has developed Methodological Recommendations for conducting an audit in the field of procurement, which reveals indicators for evaluating the effectiveness of budget expenditures on procurement (Table 2) (Methodological recommendations for conducting an audit in the field of procurement). 
Table 2. Indicators for evaluating the effectiveness of public procurement expenditures

\begin{tabular}{|c|c|}
\hline Indicator & The contents \\
\hline $\begin{array}{c}\text { Potential budget savings at the } \\
\text { stage of formation and } \\
\text { justification of the maximum } \\
\text { starting price of contract }\end{array}$ & $\begin{array}{c}\text { Makes the difference between the maximum starting price of } \\
\text { contract in the procurement schedule and the average price of } \\
\text { contracts of other customers for identical goods, works, services, } \\
\text { or the average market prices of the contract for such goods, } \\
\text { works, services }\end{array}$ \\
\hline $\begin{array}{c}\text { The economy of public } \\
\text { resources in the } \\
\text { implementation of the } \\
\text { procurement }\end{array}$ & $\begin{array}{c}\text { Difference between the maximum starting price of contract } \text { and } \\
\text { the price of the concluded contract }\end{array}$ \\
\hline $\begin{array}{c}\text { Additional budget savings } \\
\text { execution of the contract }\end{array}$ & $\begin{array}{c}\text { It is calculated as a gratuitous, voluntary provision by the } \\
\text { supplier of additional goods, works or services }\end{array}$ \\
\hline $\begin{array}{c}\text { Saving public funds in the } \\
\text { the quantity and quality of the goods, the amount of work or } \\
\text { services remain unchanged }\end{array}$ \\
\hline $\begin{array}{c}\text { Overall savings in public } \\
\text { resources }\end{array}$ & $\begin{array}{c}\text { The amount of savings at all stages of the purchase by summing } \\
\text { up the above indicators }\end{array}$ \\
\hline $\begin{array}{c}\text { Absolute amount of savings (in } \\
\text { monetary terms) }\end{array}$ & $\begin{array}{c}\text { Is the difference between the maximum starting price of contract } \\
\text { and the sum of contracts concluded less the sum of non- } \\
\text { concluded contracts and procurement costs for a certain period }\end{array}$ \\
\hline $\begin{array}{c}\text { Relative amount of budget } \\
\text { savings (as a percentage) }\end{array}$ & $\begin{array}{c}\text { It is expressed in relation to the absolute savings to the total } \\
\text { amount of maximum starting price of contract for a certain } \\
\text { period }\end{array}$ \\
\hline
\end{tabular}

The Ministry of Education and Science of the Russian Federation, for example, when assessing the effectiveness of procurement is guided by the order of March 7, 2018 No. R-130 "On approval of the list of indicators characterizing the effectiveness of procurement of goods, works, services, including subordinate organizations of the Ministry of Education and Science of the Russian Federation"), highlighting six main indicators that reflect the importance and significance (Order No. R-130 of March 7, 2018).

Table 3. The List of indicators that characterize the effectiveness of procurement, works, and services, including by subordinate organizations of the Ministry of Education and Science (Order No. R-130 of March 7, 2018)

\begin{tabular}{|c|c|c|c|c|}
\hline $\mathrm{N}$ & Indicator & The source data & Source of source data & $\begin{array}{l}\text { Measure- } \\
\text { ment } \\
\text { formulas }\end{array}$ \\
\hline 1 & 2 & 3 & 4 & 5 \\
\hline \multirow[t]{2}{*}{1.} & \multirow{2}{*}{$\begin{array}{l}\text { Percentage of } \\
\text { purchases with } \\
\text { violations of the } \\
\text { established planning } \\
\text { procedure } \\
\text { (implementation of } \\
\text { unscheduled } \\
\text { purchases, non- } \\
\text { implementation of } \\
\text { purchases according } \\
\text { to the procurement } \\
\text { schedule }(\%)\end{array}$} & $\begin{array}{l}\text { Number of purchases } \\
\text { made with violations } \\
\text { of their planning }(\mathrm{Q} 1)\end{array}$ & $\begin{array}{l}\text { Information about } \\
\text { purchases in the } \\
\text { procurement schedule, } \\
\text { including contracts } \\
\text { concluded with a single } \\
\text { supplier (contractor, } \\
\text { contractor) }\end{array}$ & $\begin{array}{c}\mathrm{P} 1=(\mathrm{Q} 1 / \\
\mathrm{Q} 2) * \\
100 \%\end{array}$ \\
\hline & & $\begin{array}{l}\text { Number of purchases } \\
\text { planned in the } \\
\text { reporting period (Q2) }\end{array}$ & $\begin{array}{l}\text { Information about } \\
\text { purchases in the purchase } \\
\text { schedule }\end{array}$ & \\
\hline 2. & $\begin{array}{l}\text { Savings in spending } \\
\text { budget funds based } \\
\text { on the results of } \\
\text { procedures }(\%)\end{array}$ & $\begin{array}{l}\text { Amount of maximum } \\
\text { starting price of } \\
\text { contract concluded } \\
\text { with a single supplier( } \\
\text { contractor, contractor) }\end{array}$ & $\begin{array}{l}\text { Information about the } \\
\text { maximum starting price of } \\
\text { contract, prices of contracts } \\
\text { concluded with a single } \\
\text { supplier (contractor, }\end{array}$ & $\begin{array}{l}\mathrm{P} 2=(\mathrm{S} 1- \\
\mathrm{S} 2 / \mathrm{S} 1) * \\
100 \%\end{array}$ \\
\hline
\end{tabular}




\begin{tabular}{|c|c|c|c|c|}
\hline & & (S1) & $\begin{array}{l}\text { contractor), in the } \\
\text { procurement schedule, the } \\
\text { customer's reporting on the } \\
\text { justification of the } \\
\text { maximum starting price of } \\
\text { contract }\end{array}$ & \\
\hline & & $\begin{array}{l}\text { Sum of prices of } \\
\text { concluded contracts } \\
\text { based on the results of } \\
\text { procedures in the } \\
\text { reporting period (S2) }\end{array}$ & $\begin{array}{l}\text { Information about } \\
\text { concluded contracts in the } \\
\text { contract register, customer } \\
\text { reporting }\end{array}$ & \\
\hline \multirow[t]{2}{*}{3.} & \multirow[t]{2}{*}{$\begin{array}{c}\text { Share of contracts } \\
\text { concluded as a result } \\
\text { of competitive } \\
\text { procedures }(\%)\end{array}$} & $\begin{array}{l}\text { Number of contracts } \\
\text { concluded in the } \\
\text { reporting period based } \\
\text { on the results of } \\
\text { competitive procedures } \\
\text { (Q1) }\end{array}$ & $\begin{array}{l}\text { Information about } \\
\text { concluded contracts in the } \\
\text { contract register, customer } \\
\text { reporting }\end{array}$ & $\begin{array}{c}\mathrm{P} 3=(\mathrm{Q} 1 / \\
\mathrm{Q} 2) * \\
100 \%\end{array}$ \\
\hline & & $\begin{array}{l}\text { Total number of } \\
\text { contracts concluded in } \\
\text { the reporting period } \\
\text { based on the results of } \\
\text { all procedures } \\
\text { (including non- } \\
\text { competitive } \\
\text { procedures) (Q2) }\end{array}$ & $\begin{array}{l}\text { Information about } \\
\text { concluded contracts in the } \\
\text { contract register, customer } \\
\text { reporting }\end{array}$ & \\
\hline \multirow[t]{2}{*}{4.} & \multirow[t]{2}{*}{$\begin{array}{l}\text { Average number of } \\
\text { bids submitted by } \\
\text { procurement } \\
\text { participants for } \\
\text { participation in } \\
\text { competitive } \\
\text { procedures (pcs.) }\end{array}$} & $\begin{array}{l}\text { Number of bids } \\
\text { submitted by } \\
\text { procurement } \\
\text { participants for } \\
\text { participation in } \\
\text { competitive procedures } \\
\text { (Q1) }\end{array}$ & $\begin{array}{l}\text { Information in minutes of } \\
\text { the procurement } \\
\text { commission }\end{array}$ & \multirow[t]{2}{*}{$\begin{array}{c}\mathrm{P} 4=(\mathrm{Q} 1 / \\
\mathrm{Q} 2) * \\
100 \%\end{array}$} \\
\hline & & $\begin{array}{c}\text { Number of competitive } \\
\text { procedures performed } \\
\text { in the reporting period } \\
(\mathrm{Q} 2)\end{array}$ & $\begin{array}{l}\text { Information in minutes of } \\
\text { the procurement } \\
\text { commission }\end{array}$ & \\
\hline \multirow[t]{2}{*}{5.} & \multirow[t]{2}{*}{$\begin{array}{l}\text { Percentage of } \\
\text { contracts in which } \\
\text { there are violations } \\
\text { of the performance of } \\
\text { obligations under the } \\
\text { contract }(\%)\end{array}$} & $\begin{array}{l}\text { The number of } \\
\text { contracts in the } \\
\text { performance of which } \\
\text { there are violations of } \\
\text { the performance of } \\
\text { obligations under the } \\
\text { contract in the } \\
\text { reporting period (Q1) }\end{array}$ & $\begin{array}{l}\text { Information on contract } \\
\text { performance in the contract } \\
\text { register, customer reporting }\end{array}$ & \multirow[t]{2}{*}{$\begin{array}{c}\mathrm{P} 5=(\mathrm{Q} 1 / \\
\mathrm{Q} 2) * \\
100 \%\end{array}$} \\
\hline & & $\begin{array}{l}\text { Number of contracts } \\
\text { executed in the } \\
\text { reporting period (Q2) }\end{array}$ & $\begin{array}{l}\text { Information about the } \\
\text { performance of the contract } \\
\text { in the register of contracts, } \\
\text { reporting of the customer }\end{array}$ & \\
\hline \multirow[t]{2}{*}{6.} & \multirow[t]{2}{*}{$\begin{array}{l}\text { Proportion of } \\
\text { justified complaints } \\
\text { about the actions } \\
\text { (inaction) of the } \\
\text { customer during the } \\
\text { procedures (\%) }\end{array}$} & $\begin{array}{l}\text { Number of justified } \\
\text { complaints about the } \\
\text { actions (inaction) of } \\
\text { the customer during } \\
\text { the procedures (Q1) }\end{array}$ & $\begin{array}{c}\text { Decisions of the Federal } \\
\text { Antimonopoly Service of } \\
\text { Russia (FAS) }\end{array}$ & \multirow[t]{2}{*}{$\begin{array}{c}\mathrm{P} 6=(\mathrm{Q} 1 / \\
\mathrm{Q} 2) * \\
100 \%\end{array}$} \\
\hline & & $\begin{array}{l}\text { Number of complaints } \\
\text { filed against the } \\
\text { actions (inaction) of }\end{array}$ & $\begin{array}{c}\text { Notifications of the FAS of } \\
\text { Russia }\end{array}$ & \\
\hline
\end{tabular}




\begin{tabular}{|l|l|l|l|l|}
\hline & $\begin{array}{c}\text { the customer during } \\
\text { the procedures in the } \\
\text { reporting period (Q2) }\end{array}$ & & \\
\hline
\end{tabular}

As we can see, all the recommended indicators evaluate only the procurement procedures that have already been carried out. In addition, these indicators affect efficiency only in the field of budget execution, bypassing any other characteristics, such as delivery times or the quality of purchased products. Many customers often face the problem of the lack of developed indicators that would allow them to analyze and predict the effectiveness of state and municipal orders before placing them. After all, such indicators can be useful both for justifying the actions of the customer, and for justifying the provision of the necessary budget funds for procurement.

In connection with the above, we consider it appropriate to include in this list a number of other important indicators in our opinion.

Table 4. The System of additional indicators for evaluating the effectiveness of public procurement expenditures

\begin{tabular}{|c|c|}
\hline $\begin{array}{l}\text { Criteria for evaluating the } \\
\text { effectiveness of procurement planning }\end{array}$ & $\begin{array}{l}\text { - Number of changes made to the procurement plan } \\
\text { and schedule; } \\
\text { - The ratio of the number of purchases made in the } 4 \text { th } \\
\text { quarter of the year to the total number of purchases for } \\
\text { the year. }\end{array}$ \\
\hline $\begin{array}{c}\text { Criteria for evaluating competitive } \\
\text { procurement }\end{array}$ & $\begin{array}{l}\text { - The ratio of the share of competitive purchases from } \\
\text { the total volume (both in quantitative and monetary } \\
\text { terms), expressed as a percentage; } \\
\text { - The ratio of failed purchases to the total volume of } \\
\text { competitive procedures, expressed as a percentage; } \\
\text { - Number of procurement participants. }\end{array}$ \\
\hline $\begin{array}{l}\text { Criteria for assessing the savings of } \\
\text { public resources }\end{array}$ & $\begin{array}{l}\text { - The ratio of the maximum starting price of contract } \\
\text { and the price of the concluded contract. }\end{array}$ \\
\hline $\begin{array}{l}\text { Criteria for evaluating compliance } \\
\text { with the law in procurement }\end{array}$ & $\begin{array}{l}\text { - Number of complaints to the Federal Antimonopoly } \\
\text { Service found to be justified; } \\
\text { - Number of changes made to the procurement } \\
\text { documentation; } \\
\text { - The results of inspections (planned, unplanned,); } \\
\text { - Number of proceedings won in court }\end{array}$ \\
\hline $\begin{array}{l}\text { Criteria for evaluating the } \\
\text { effectiveness of document } \\
\text { management }\end{array}$ & $\begin{array}{l}\text { - Timing of preparation and submission of the } \\
\text { documentation for the purchase; } \\
\text { - Deadlines for evaluating applications; } \\
\text { - Terms of conclusion of contracts }\end{array}$ \\
\hline
\end{tabular}

\section{Conclusions}

Ideally, public procurement will have the greatest effect if:

- the requirements for planning, rationing, calculation, justification of the maximum starting price of contract will be met, and the transparency of procurement will be ensured;

- at least two applications will be submitted to ensure competition;

- formal compliance with all legal requirements by the customer will be achieved;

- a reduction in the price of public procurement will be achieved;

- the contract will be concluded without violations.

The use of a wider range of criteria for the effectiveness of procurement activities will avoid a significant bias towards the effectiveness of budget expenditures in their assessment. Qualitative characteristics of the evaluation of the effectiveness of public procurement can become an innovative tool in assessing the effectiveness of public procurement

\section{References}


Budget Code of the Russian Federation No. 145-FZ of 31.07.1998 (as amended by No. 62-FZ of 15.04.2019) (as amended on 08.06.2020).

Federal Law "On procurement of goods, works, services by separate types of legal entities" of 18.07.2011 No. 223-FZ (as amended on 24.04.2020).

Federal Law No. 98-FZ of 01.04.2020 "On Amendments to certain legislative Acts of the Russian Federation on the prevention and elimination of emergency situations" (as amended on 08.06.2020).

Federal law of 01.04.2019 No. 50-FZ "On amendments to the Federal law "On contract system in procurement of goods, works, services for state and municipal needs".

Home procurement Portal (EIS) [Electronic resource] / - Electron. dan. - Access mode: //http://zakupki.gov.ru/epz/main/public/home.html

Lapin, A. E., Kiseleva, O. V., Kumundzhieva, E. L. (2016). Business. Education. Right. Journal "Bulletin of the Volgograd Institute of Business", 1(34), 30-35 [Electronic resource] / Electron. dan. - Access mode: http://vestnik.volbi.ru/upload/numbers/134/article-1341548.pdf

Methodological recommendations for conducting an audit in the field of procurement/ Accounts Chamber of the Russian Federation / / approved by the Collegium of the Accounts Chamber of the Russian Federation (Protocol No. 15K (961) - 60 p. dated March 21, 2014).

On the contract system in the field of procurement of goods, works, services for State and Municipal Needs: Federal Law No. 44-FZ of 05.04.2013. [Electronic resource] / Consultant-plus. - Electron. dan . - Access mode: http://www.consultant.ru

Order No. R-130 of March 7, 2018 "On approval of the list of indicators characterizing the effectiveness of procurement of goods, works, services, including by subordinate organizations of the Ministry of Education and Science of the Russian Federation" [Electronic resource] / Consultant-plus - Electron.Dan. - Access mode: http://www.consultant.ru/document/cons_doc_LAW_300012/(accessed 20.04.2020).

the Order of March 7, $2018 \mathrm{n} \mathrm{R}-130$ "On approval of the list of indicators characterizing the efficiency of procurement of goods, works, services, including subordinate organizations of the Ministry of education and science of the Russian Federation". 